\title{
Evaluation of the Teaching of Physical Education and Sports Activities by Students in Physical Education
}

\author{
Lembe Gorgon ${ }^{*}$, Ewamela Aristide ${ }^{1}$, Makoyi Ngouala Marc Deye ${ }^{1}$, \\ Goma Ndembi Darell Ferrand1, Massamba Alphonse ${ }^{2}$
}

${ }^{1}$ Laboratory of Didactics of Physical Education, Higher Institute of Physical and Sports Education, Marien Ngouabi University, Brazzaville, Congo

${ }^{2}$ Laboratory of Biomechanics and Movement Analysis, Higher Institute of Physical and Sports Education, Marien Ngouabi

University, Brazzaville, Congo

Email: *drgorgonlembe@gmail.com

How to cite this paper: Gorgon, L., Aristide, E., Deye, M. N. M., Ferrand, G. N. D., \& Alphonse, M. (2020). Evaluation of the Teaching of Physical Education and Sports Activities by Students in Physical Education. Creative Education, 11, 864-880. https://doi.org/10.4236/ce.2020.116062

Received: May 9, 2019

Accepted: June 21, 2020

Published: June 24, 2020

Copyright (c) 2020 by author(s) and Scientific Research Publishing Inc. This work is licensed under the Creative Commons Attribution International License (CC BY 4.0).

http://creativecommons.org/licenses/by/4.0/

(c) (i) Open Access

\begin{abstract}
Objective: This study aims to assess by the students of the master's degree in physical education the quality of course content, assessment methods and adopted teaching strategies implemented by the trainers. Method: The investigation was based on a questionnaire relating to the objectives of the lessons given, the educational strategies, the methods and results of the assessments, and the supervision of the students. The response to each item of the questionnaire was assessed using a Likert descriptive-digital scale at 4 levels. Results: The formulation of the teaching objectives proved to be relevant and their achievement had been acquired at the end of the learning. Regarding the adaptability of course content, the lessons were complete and rigorous for $81.1 \%$ of the students, and the quality of work was balanced for $72.2 \%$ of them. The courses provided favored sufficient participation for $74.4 \%$ of the students, and the mode of assessment of learning was appropriate. Regarding the feeling of having developed skills, $71.1 \%$ of students held back general skills, $57.7 \%$ for transversal skills, and $56.7 \%$ for specific skills. Finally, good structural and institutional organization of teaching was satisfactory: schedule and pace of the lessons, $64.4 \%$; hourly volume allocated to the lessons, $71.1 \%$; material conditions, $68.9 \%$.
\end{abstract}

\section{Keywords}

Physical Education, Teaching Evaluation, Master Students, Trainer, Higher Education 


\section{Introduction}

University pedagogy does not have a long history, at most four to five decades. As in other areas, its scope has gradually widened, and in several directions. Originally, these were the most professionalizing scientific fields which were the first and most active to conduct analyses and research on the quality of their university training. Little by little, other faculties or departments followed the movement, which has accelerated in recent years under the pressure of different factors: important international meetings such as the World Congress of Higher Education organized in Paris by Unesco in 1998, major political events such as the Bologna Meeting and the Lisbon Summit, multiplication of educational resource centers within universities, emergence of international and national associations aimed at improving the quality of university education (De Ketelé, 2010). It is in this context that the teaching profession has experienced a process of professionalization in recent decades, passing from occupations to professions, from empirical knowledge to scientific knowledge. Some analyses have nonetheless identified recurrent criticisms in the discourse of those involved in education, with regard to knowledge considered too theoretical and inappropriate, especially in the effective preparation of future teachers (Poissant, 1996; Lanares, 2009; De Ketelé, 2010). The question set out by Bru (2002a) has not lost its relevance twenty years later: how can the conditions for a more sustained exchange between research knowledge and the knowledge of education professionals be met?

The evaluation of teaching by students (EEE) has, since its introduction in the 1960s on the North American continent, raised doubts and controversies (Caverlind, 2005; Bravranmps \& Ory, 1994; Hiebert, Gallimore, \& Stigler 2002). Many researchers in the humanities then examined the question and highlighted the relevance of this form of evaluation, provided that various precautions are observed (Doyle, 1983; Seldin, 2006). However, a common idea is that students would not be able to judge the validity of an education. This idea expressed in the form of "only my peer teachers or educational experts can give an objective opinion on my practice" is certainly one of the most widespread. Evaluating the quality of teaching thus appears to be a difficult exercise, with direct consequences on the university environment, whether it be symbolic. As such, it may seem delicate to ask students strongly involved in the teaching relationship to assess their teachers.

However, it is admitted to consider the evaluation of teaching by students as a useful indicator for the understanding of university teaching, as indicated by Braskamp and Ory (1994): "students are empowered to judge certain aspects of a teaching, those which refer to their learning experience". Indeed, the teaching-learning process being complex, its evaluation thus requires the use of a method taking into account all of all the dimensions that cover it in its entirety. This is how Bernard (2011a) considers that evaluating a teacher's teaching means gathering information on the quality of his teaching work. This author 
added that the answers to the questions: What information should be collected? What are the important dimensions of education to focus on in order to carry out a valid, relevant and exhaustive assessment?

The evaluation of lessons at the Marien Ngouabi University of Congo was only carried out ten years ago since the creation of the Center d'Enseignement Supérieur de Brazzaville in 1958 with authority over French Equatorial Africa before independence, which became the University of Brazzaville in 1964 and the Marien Ngouabi University in 1978. Today, this process makes it possible to judge the quality of the training offered by the teachers and to strengthen communication with the students. However, to our knowledge, no study has focused on the evaluation of physical education lessons (PE) by students in training, whereas this assessment would be an instrument to control the value of training and the quality of teaching. As a former EPS teacher in high schools in the Congo and currently a teacher-researcher at the institute in charge of training future physical education teachers, we deemed it necessary to reflect on this theme. It is in this perspective that we conducted this research which answers the following central question: What are the perceptions of didactico-pedagogical practices of teachers by Congolese students in PE? Two secondary questions are corollaries to this main question: 1) Do the didactico-pedagogical strategies and devices implemented by the teachers require the support of the students? 2) What are the contextual effects on the supervision of students?

We hypothetized that: 1) the learning objects proposed by the teachers are well developed, but they are unsuitable in terms of achievement of objectives, quantification of work, quality of materials, availability and interactive exchanges thus leading on student dissatisfaction; 2) the planning and the pace of the context-dependent supervision activities are not in line with the expectations of the students.

This study aims to assess by the students of the master's degree in physical education the quality of course content, assessment methods and adopted teaching strategies implemented by the trainers. The interest of this study is to allow teachers to become aware of the requirements of the training mission and to improve their practices, with a view to developing ethical and professional skills among students in the era of quality assurance of training. It is part of the overall effectiveness of improving teaching and training in PE in order to prepare for the attractiveness, visibility and competitiveness of the training offer.

\section{Materials and Methods}

\subsection{Study Setting}

The analytical and cross-sectional study was conducted from March 5 to June 13, 2019 in Brazzaville, capital of the Congo City that houses the one and only public university in the country. This institute is the first training establishment for executives in PE in French-speaking black Africa to be attached to a university structure when it was created in 1975 . 


\subsection{Participants}

The population consisted of all undergraduate and master's students in PE, pedagogical supervision and sports from the Higher Institute of Physical and Sports Education, Marien Ngouabi University in Brazzaville. However, our study focused only on master students $(\mathrm{N}=102)$. The choice of this population is justified by the systematic recruitment of these students at the end of the training within the Public Service of the Congo, particularly at the Ministry of National Education. They must then exercise the functions of either a physical education teacher or a pedagogical inspector in high schools. The evaluation of the teaching provided by the trainers who intervene in the master seems to us relevant and judicious. The inclusion criteria were: regularity in courses and seminars; consent to participate in the study. The sample was 90 students enrolled in a master's in PE, pedagogical supervision and sports, during the 2018-2019 academic year.

\subsection{Finding Aids}

The data collection instrument was the questionnaire. This survey questionnaire carries five evaluation objects which aimed to recognize high quality teaching: the objectives of the course; course content; teaching strategies and course materials; the methods for evaluating learning and student supervision.

The questionnaire, in terms of its structure, included: 3 items bearing the objectives of the course, 3 items on the course content, 6 items on the teaching strategies and material of the course, 6 items on the evaluation of learning, 4 items on supervision of students. Each item was evaluated according to a $\mathrm{Li}$ kert-type descriptive-numerical rating scale, ranging from 1,3 to 4 . The response methods are represented by: "strongly disagree", "disagree", "agree" and "strongly agree".

\subsection{Data Analysis}

Data are expressed in terms of number and percentage. The comparison of two percentages was examined using the Sokal S test (Sokal \& Rohlf, 1995); for more than two percent, it was the Fisher test. The data was entered by the Epi Info software version 6.1.0, then transported in the SPSS software version 25.0 (Chicago, IL, USA). $p<0.05$ is the significance level of the tests.

\section{Results}

\subsection{Course Objectives}

The students' answers to the questions related to defining objectives, respecting the stated objectives and achieving the objectives pursued are presented in Table 1.

It appears from the analysis in Table 1 that the responses of $67.8 \%$ of students on the clear definition of the teaching objectives converged more towards "agree" $(p<0.01)$. However, in order to meet the stated objectives, $65.5 \%$ of the students $(p<0.05)$ were more inclined towards "strongly disagree". Likewise, 
when reaching the objectives pursued, $68.9 \%$ of the students more often mentioned "strongly disagree" $(p<0.001)$.

\subsection{Course Content}

The scores relating to the responses obtained in relation to the content of the courses are shown in Table 2.

In total, $42.2 \%$ of students underlined the adaptability of the content of the lessons to the prior knowledge and to the level of knowledge on the content of the, the difference being not significant $(p>0.05)$. Likewise, for consistency and complementarity with the other lessons on content, the difference in responses was not significant $(p>0.05)$. On the other hand, education appeared complete and rigorous for $81.1 \%$ of the students with a significant difference $(p<0.001)$ in favor of "totally agree".

\subsection{Teaching Strategies and Course Materials}

Student responses are listed in Table 3.

The values recorded in Table 3 indicate that $44.4 \%$ of the students $(p>0.05)$ answered "totally agree" regarding the importance of the lessons learned for the professional project. However, for the amount of work requested by teachers, $72.2 \%$ of students $(p<0.01)$ answered "okay". But for the adaptation of the pedagogical approach to the level of knowledge and training, $54.4 \%$ of the students were in favor of "completely agree" $(p>0.05)$. Similarly for the availability of

Table 1. Students' opinions on course objectives.

\begin{tabular}{cccccc}
\hline & $\begin{array}{c}\text { Not agree } \\
\text { at all n (\%) }\end{array}$ & $\begin{array}{c}\text { Disagree } \\
\mathbf{n}(\%)\end{array}$ & $\begin{array}{c}\text { Okay } \\
\mathbf{n}(\%)\end{array}$ & $\begin{array}{c}\text { Strongly } \\
\text { agree n (\%) }\end{array}$ & $\boldsymbol{p}$ \\
\hline Teaching objectives are clearly defined & $17(18.9)$ & $5(5.5)$ & $51(67.8)^{\star *}$ & $7(7.8)$ & $<0.01$ \\
The stated objectives are respected & $59(65.5)^{*}$ & $6(4.4)$ & $25(27.8)$ & $10(11.1)$ & $<0.05$ \\
The objectives pursued are achieved & $52(68.9)^{\star *}$ & $18(20)$ & $6(6.7)$ & $4(4.44)$ & $<0.01$ \\
\hline
\end{tabular}

Marks: ${ }^{\star} p<0.05 ;{ }^{\star *} p<0.01$.

Table 2. Evocations of students on the adaptation of content adapted to prior learning and the level of knowledge on consistency and complementarily with other courses, on the effectiveness of teaching compared to expectations.

\begin{tabular}{lccccc}
\hline & $\begin{array}{c}\text { Not agree } \\
\text { at all } \mathbf{n}(\%)\end{array}$ & $\begin{array}{c}\text { Disagree } \\
\mathbf{n}(\%)\end{array}$ & $\begin{array}{c}\text { Okay } \\
\mathbf{n}(\%)\end{array}$ & $\begin{array}{c}\text { Strongly agree } \\
\mathbf{n}(\%)\end{array}$ & $P$ \\
\hline $\begin{array}{c}\text { The teaching content is adapted to } \\
\text { previous knowledge, to the level of } \\
\text { knowledge }\end{array}$ & $9(10.1)$ & $12(13.3)$ & $31(34.4)$ & $38(42.2)$ & $P>0.05$ \\
$\begin{array}{c}\text { The content of the teaching is } \\
\text { consistent and complementary with } \\
\text { the other lessons of the training }\end{array}$ & $10(11.1)$ & $18(20)$ & $27(30)$ & $35(38.9)$ & $P>0.05$ \\
$\begin{array}{c}\text { The teaching seems complete and } \\
\text { rigorous }\end{array}$ & $2(2.2)$ & $6(6.7)$ & $9(10)$ & $73(81.1) * * *$ & $<0.001$ \\
\hline
\end{tabular}

Mark: ${ }^{* *} p<0.001$. 
teachers, $58.9 \%$ of student responses $(p<0.05)$ converged towards "totally agree". In addition, for $43.3 \%$ of students, opinions relating to the mode of transmission of knowledge leaned towards "totally agree" ( $p>0.05)$. Finally, for the quality of the materials, the student response rates agree "totally agree" $44.4 \%(p>0.05)$.

\subsection{Assessment Methods for Learning}

The opinions of students on the methods for evaluating learning are presented in Table 4.

Table 4 shows that for $74.4 \%$ of the students, education provided sufficient participation $(p<0.01)$. For the appropriate mode of assessing knowledge, $71.1 \%$ of students answered "strongly disagree" $(p<0.001)$. As for the students' responses on the feeling of being assessed correctly and fairly, $67.7 \%$ of them "totally agree" $(p<0.01)$. Whereas on the feeling of having developed general skills $71.1 \%$ of the students recognized it $(p<0.01)$. Regarding the feeling of having developed transversal skills, $57.7 \%$ of the responses obtained leaned towards "not at all in agreement" $(p<0.05)$. The same was true for the feeling of having developed the specific skills, with $56.7 \%$ of responses "strongly disagree" $(p<0.05)$.

Table 3. Evocations of students on teaching strategies and course materials.

\begin{tabular}{ccccccc}
\hline & $\begin{array}{c}\text { Not agree } \\
\text { at all } \mathbf{n}(\%)\end{array}$ & $\begin{array}{c}\text { Disagree } \\
\mathbf{n}(\%)\end{array}$ & $\begin{array}{c}\text { Okay } \\
\mathbf{n}(\%)\end{array}$ & $\begin{array}{c}\text { Strongly } \\
\text { agree n (\%) }\end{array}$ & $p$ \\
\hline $\begin{array}{c}\text { The contributions of the lessons are } \\
\text { important for the professional project }\end{array}$ & $11(12.3)$ & $14(15.5)$ & $28(31.1)$ & $37(41.1)$ & $p>0.05$ \\
$\begin{array}{c}\text { The amount of work required is balanced } \\
\text { The educational process }\end{array}$ & $5(5.6)$ & $8(8.9)$ & $65(72.2)^{* *}$ & $12(13.3)$ & $<0.01$ \\
is adapted to the level & $13(13.4)$ & $6(6.7)$ & $32(35.5)$ & $49(54.4)^{*}$ & $<0.05$ \\
of knowledge and type & $3(1.1)$ & $7(7.8)$ & $29(32.2)$ & $51(58.9)^{*}$ & $<0.05$ \\
Training & $7(7.8)$ & $12(13.4)$ & $32(35.5)$ & $39(43.3)$ & $p>0.05$ \\
& $6(6.7)$ & $16(17.8)$ & $28(31.1)$ & $40(44.4)$ & $p>0.05$ \\
\hline
\end{tabular}

Marks: ${ }^{\star} p<0.05 ;{ }^{* *} p<0.01$.

Table 4. Students' opinions on sufficient participation, appropriation of the evaluation method, evaluation and skills development.

\begin{tabular}{cccccc}
\hline & $\begin{array}{c}\text { Not agree at } \\
\text { all n (\%) }\end{array}$ & $\begin{array}{c}\text { Disagree } \\
\mathbf{n}(\%)\end{array}$ & $\begin{array}{c}\text { Okay } \\
\mathbf{n}(\%)\end{array}$ & $\begin{array}{c}\text { Strongly } \\
\text { agree n (\%) }\end{array}$ & p \\
\hline $\begin{array}{c}\text { Education allows sufficient } \\
\text { participation, }\end{array}$ & $10(12.3)$ & $13(14.4)$ & $8(8.9)$ & $67(74.4)^{* *}$ & $<0.01$ \\
sharing ideas and knowledge & $64(71.1)^{* *}$ & $3(3.3)$ & $21(23.3)$ & $2(2.3)$ & $<0.01$ \\
The method of evaluating & $20(22.2)$ & $7(7.8)$ & $2(2.3)$ & $61(67.7)^{* *}$ & $<0.01$ \\
Knowledge is appropriate & $7(7.8)$ & $10(11.1)$ & $64(71.1)^{* *}$ & $9(10)$ & $<0.01$ \\
The assessment is correct and & $52(57.8)^{*}$ & $13(14.4)$ & $9(10)$ & $16(17.8)$ & $<0.05$ \\
Fair & $51(56.7)^{*}$ & $15(16.7)$ & $4(4.4)$ & $20(22.2)$ & $<0.05$ \\
\hline
\end{tabular}

Marks: ${ }^{*} p<0.05 ;{ }^{* *} p<0.01$. 


\subsection{Knowledge of the Examination System and Knowledge Control Procedures at the Start of the Semester}

The responses relating to the students' opinions on knowledge of the examination system and knowledge control methods at the start of the semester revealed $32.2 \%(n=29)$ of affirmative responses and $67.8 \%(n=61)$ of responses negative, the difference between the two percentages being significant $(p<0.05)$.

\subsection{Supervision of Students}

The opinions of the students at the level of the organization of the tests, the planning, the rhythm of the courses, the material conditions and the hourly volume of the lessons are contained in Table 5.

Regarding satisfaction with the organization of the test, the responses of $40.1 \%$ of the students converged on "completely agree" ( $p>0.05)$. However, the responses of $64.4 \%$ of the students $(p<0.01)$ converged towards "completely agree" in terms of satisfaction with the schedule and the pace of the lessons. For the hourly volume allocated to lessons, $71.1 \%$ were "in agreement" $(p<0.01)$. In addition, $68.9 \%$ of the students $(p<0.01)$ were satisfied with the material conditions.

\section{Discussion}

This study of which the goal was to assess the quality of theoretical teaching in PE by students from Congo Brazzaville, mainly allowed master students of physical education to know where they were with the lessons received and the skills developed, which should make it possible to give meaning to the teacher's behavior.

\subsection{Course Plan and Content}

The results obtained from this study carried out in Congo show first of all that the opinions of the students on the clear definition of the objectives of the teachings by the teachers, converged towards "agree" significantly ( $68.74 \%$ of the responses; $p<0.01$, Table 1 ). These results can be explained by the contract between the trainer and learners. Teachers working in master's programs thus

Table 5. Evocations of students on coaching.

\begin{tabular}{lccccc}
\hline & $\begin{array}{c}\text { Not agree } \\
\text { at all } \mathbf{n}(\%)\end{array}$ & $\begin{array}{c}\text { Disagree } \\
\mathbf{n}(\%)\end{array}$ & $\begin{array}{c}\text { Okay } \\
\mathbf{n}(\%)\end{array}$ & $\begin{array}{c}\text { Strongly } \\
\text { agree } \mathbf{n}(\%)\end{array}$ & $\mathbf{p}$ \\
\hline $\begin{array}{c}\text { The organization of the event is } \\
\text { satisfactory }\end{array}$ & $13(14.4)$ & $18(20)$ & $23(25.5)$ & $36(40.1)$ & $>0.05$ \\
$\begin{array}{c}\text { The schedule and the pace of the } \\
\text { lessons are satisfactory }\end{array}$ & $5(5.5)$ & $11(12.3)$ & $16(17.8)$ & $58(64.4)^{* *}$ & $<0.01$ \\
$\begin{array}{c}\text { The hourly volume allocated to the } \\
\text { lessons is suitable }\end{array}$ & $6(6.7)$ & $9(10)$ & $64(71.1)^{* *}$ & $11(12.2)$ & $<0.01$ \\
\begin{tabular}{c} 
Material conditions are satisfactory \\
\hline
\end{tabular} & $5(5.5)$ & $13(14.4)$ & $62(68.9)^{* *}$ & $10(11.2)$ & $<0.01$ \\
\hline
\end{tabular}

Mark: ${ }^{* *} p<0.01$ 
clearly define the objectives. For Cros (2012), an educational objective is what the learner will be able to do after the training. In the same sense, the same author stipulates that the pedagogical objectives designate the behaviors that the learner must be able to perform after learning. The latter is used to develop a skill that can be expressed in terms of ability. However, $65.5 \%$ of the students ( $p$ $<0.05)$ leaned towards "strongly disagree" regarding the respect of the objectives stated in the teachings. This contrast in responses, attributable to the vague formation of the objectives stated by the teachers, gives rise to multiple interpretations, or even misguided. In this regard, Amade-Escot (1991) states that teachers must build all their activity on clear objectives, but they must also make these, without ambiguity or mystery, known to their students. It therefore seems inconceivable that a teacher knowing what he wants to teach, does not choose from the start his teaching method. However, we believe that there are teachers who are aware of the goal, but too lazy or too lacking to deploy the necessary strategies. Regarding the achievement of the objectives, $68.9 \%$ of the students said, "strongly disagree" with a highly significant difference in percentages $(p<$ 0.01 ). This reflects the unhealthy spirit that dominates these teachers. In this regard, Bourgeois (2006) finds that one of the best proofs of the unhealthy spirit which dominates a teaching not focused on explicit objectives, lies in the fact that students must apply themselves to guess what is important either by an analysis of the manuals or the types of questions asked in the interrogations, or even by collecting information from their elders. Now on this subject, It is known that to formulate an objective is to define it. This formulation consists, starting from each of the skills listed, in defining a general objective which will be broken down into several specific objectives.

Thus, it must comply with certain requirements, to guarantee their operational nature. On this subject, Hein and Koka (2007) characterize the general requirements or principles of stating an educational objective. According to these authors, for an educational intention to become operational:

- its content must be stated as unequivocally as possible;

- this intention must describe an activity of the student identifiable by observable behavior;

- it must mention the conditions under which this behavior must occur;

- it must indicate the level of requirement to which the learner is required to be placed, and the criteria which will be used to assess this learning.

In addition, our results from our consolidate the ideas of Cyruslink (2014), who indicates that the educational objectives make it possible to precisely determine the expected results in terms of knowledge, attitudes and behavior of the learner at the end of the activities' learning. They guide the choice of teaching, that is to say, oblige teachers to think and prepare their activities in a precise, specific and detailed manner. They also allow teachers to make a judicious choice of teaching-learning methods and techniques, adequate teaching material, class organization and means of evaluation. In addition, the educational objec- 
tives promote the transmission of knowledge from the teacher and the acquisition of knowledge from the learner. The dominance of "strongly disagree" shows how the stated objectives are neither respected nor achieved.

Furthermore, the non-significant difference in the percentages relating to the responses on adaptability to prior learning and level of knowledge on the content of the lessons, although in favor of "totally agree" (Table 2), can be attributed to the student learning experience. Indeed, students are empowered to judge certain aspects of education, especially those that refer to their learning experience (Braskamp \& Ory, 1994). On the other hand, Poissant (1996) reported on this subject that students are not able to assess aspects related to the content of a course or the amount of knowledge of a teacher in his field. From this observation, we believe that evaluation by students can therefore be considered as a relevant tool, but this does not make it possible to measure all the dimensions of an education. It is therefore necessary to extend the means of student evaluation, for example to classroom observation or even self-assessment. As for consistency and complementarily with the other lessons on content, the difference between the percentages linked to the responses is not significant with a relatively high proportion of "completely agree". This is dependent on the widening of the field of university pedagogy. Indeed, De Ketelé (2010) demonstrated that the widening of the field of university pedagogy took place mainly at the conceptual level, like what happens with the concept of pedagogy, which initially means art act on children, while it has opened up over time to all categories of learners (pupils, students, adults in continuing education, professionals, trainers). If, initially, the accent is put on educational activities within universities (teaching activities and later, learning activities), it quickly appears that these can hardly be studied. Isolation, so important is the interplay of relationships with other components. It is in this context that English-speaking universities, the first to justify the need for this expansion (notably through the publications published in the Review of Higher Education, were quickly followed by the pioneers of the International Association of University Teaching in 1970s (Parmentier, De Ketele and Gerard. 2007). On this subject, Bru (2002b) adds that the quality of training is not reduced to the juxtaposition of teaching, whatever the quality, but depends rather of its coherence, in particular of the articulation of the teachings between them. On the other hand, the teaching appears complete and rigorous with a significant percentage difference $81.1 \%$ of the answers $(p<$ 0.001 ) in favor of agree. "This contrast may be reflected in the fact that effective teaching is representative of our students surveyed. Moreover, Reboul (1980) emphasizes that teaching, as a long-term activity, takes place in a specific institution, entrusted to competent people, and whose aim is to allow the taught to acquire skills, organized and transferable knowledge, by developing their critical spirit.

The notion of education allows us to try to clarify what are the really necessary and sufficient conditions. Teaching as a transmission of knowledge is based on 
perception, in particular through oratory and writing. The teacher's presentation, the use of texts, participation techniques and student debate are some of the methods used during the teaching process. This is how we distinguish teaching centered on learning or performance.

\subsection{Assessment of Learning and Transmission of Knowledge}

Regarding the importance of the contributions of the lessons for the professional project, the percentages of the students answered with "completely agree" present an insignificant difference (Table 3). This can be understood by the professional development of university teachers. Indeed, Paquay, Nieuwenhoven \& Wouters (2010) report that professional development mainly consists in the construction of skills and identity transformations in work situations during the career. In this regard, it has been clearly established that teaching constitutes one of the fields of professional activity of university teachers, in the same way as research, supervision and university administration (Brookfield, 1992). In most higher education systems, university teachers are trained almost exclusively in research; which means that their expertise in other areas of their professional activity generally develops in their workplace. Professional development, in such circumstances, depends on mechanisms such as reflective practice, i.e. the systematic analysis of one's actions and experiences in order to identify principles that can guide any future action (Calderhead, 1992; Schön, 1983).

In addition, this reflective practice, supported by feedback from students, colleagues or other actors in the university environment, allows university teachers to develop a knowledge base for teaching that is both rich and validated (Hiebert et al., 2002). In a system where teacher training is institutionally poorly formalized, professional development results mainly from a voluntary enterprise: university teachers devote time to thinking about their practices, to the impact of their practices on the students' learning in order to identify principles which will help them build their pedagogical knowledge base. This calls for great personal discipline and considerable intrinsic motivation.

In this regard, it is interesting to note, as Cordova \& Lepper (1996) point out, that intrinsic motivation is increased when learning environments are personalized and that they leave room for choice for the student. Thus, for university teachers, who most often learn their trade in a work situation, reflective practice may lead to increased professional development if the context in which they carry out this learning supports their motivation and their development (for example adaptability various assessments or resources supporting reflection), while respecting the diversity of visions and aspirations for professional development fostered by the teachings (Akerlind, 2005).

Regarding the balance of the amount of work required by teachers, $72.2 \%$ of students answered in favor of "agree" with a highly significant difference ( $p<$ $0.001)$. This is reflected in the effects of the assessment on master students. Indeed, Rossi \& Freeman (1985) mentioned that the effects of evaluation have a 
positive impact on the education system, the authors emphasize that it is important that the evaluation is the object of an appropriation by stakeholders and internal decision-makers in the education system. This determines the regulation that can ensue, since internal evaluation involves regulatory devices supported by instrumentation allowing "feedback" on teaching activities.

Compared to the responses associated with the adaptation of the pedagogical approach to the level of knowledge and training, the responses obtained from the students are in favor of "completely agree", the difference being nonetheless not significant. This fact is partly explained by the progression of university pedagogy. Similarly for the availability of teachers, the student responses converge towards "completely agree" with an insignificant difference. This is understandable by the Student Teacher Assessment (EEE) aimed at the professional development of teachers. Bernard, Postiaux, \& Salcin (2000), Coggi \& Maccario (2009) have reported on this subject that the feedback received from students within the framework of the EEA can provide information that is most useful to the teacher, especially if these are crossed with others such as test results.

As for opinions on the mode of transmission of knowledge, $43.3 \%$ of students answered "completely agree", with a difference in percentages not significant. Our observations are in line with those of Piccinin (1999), who underline the extent to which a student evaluation of teaching (EEE) approach based on counseling has a much more significant impact on teachers. The system of Teacher Assessment by Students offered within an institution acts as a strategy to support educational development. The EEE can therefore become one of the strategies to support the professional development process of university teachers and thus act as a complement to other strategies such as advice, training or research applied to university education, sometimes even by initiating them.

In terms of the quality of the materials, $44.4 \%$ of the responses from the students obtained reported "completely agree", with a non-significant difference. Overall, our results on pedagogical strategies (Table 3) are similar to those obtained by the Analysis Committee of the Training Program of the Quebec School (2009). In fact, this Committee, working in the field with teachers, has identified the need to make students work harder; they need to be more active. They are the ones who should be tired at the end of the course. Current students, like ours, have more skills; they invest faster and are more demanding. You have to contextualize the tasks all the time; if we just distribute knowledge, they'll be bored.

Only, ISEPS master students fully agree with the quality of the supports given to them by teachers. This can be linked to the pedagogical strategies that teachers use. These strategies include various teaching methods, which in turn include different teaching techniques.

Furthermore, $74.4 \%$ of the students' responses on effective course participation, sharing of ideas and knowledge were "completely in agreement" $(p<0.01$; Table 4). These results suggest the EEA formative nature in that it provides in- 
formation on teaching practices, with regard to a certain number of criteria which establish an "effective" teaching: planning and organization of lessons and evaluation of learning (Bernard, 2011b). Improvement of lessons is then based on changes that lead to higher efficiency indicators. The efficiency criterion is then valued and deserves an analysis by itself. But before looking at efficiency, it is necessary to consider utility. Perret \& Demougeot-Lebel (2014) reported that the nature of the information provided to teachers is important in the reflective process, as certain information can give rise to actions more directly achievable by the teacher. There is also a need to take into account the use of student perspectives by university teachers.

\subsection{Assessment Methods and Developed Skills}

A total of $74.1 \%$ of the students "totally disagreed" on the method of assessing knowledge, whether it seemed appropriate or not, the difference between the percentages of responses being significant $(p<0.05$ Table 4). This proves how many times the teachers have given work to them. According to Bélair (1996), the courses given at the university have little impact on the learning achieved by the students compared to the situations which are much more influential. Baillauquès (1996) emphasizes, among other things, that knowledge of the teaching environment, through experience and studies, highlights that there is a problem for teachers on the training side. Furthermore, in a study on the influences of the educational environment offered by universities and on the ways in which students learn (Romainville, 1997). For this author, "the students' perception of the specifics of their discipline, their sector of study, the education received, the tasks and the evaluation system influences their choice of approach to study and learning strategies "(p. 96). Other research has shown that students who invest more in their studies, more frequently use strategies that allow significant learning when the training is centered on the student (the program is oriented towards taking responsibility, the course structure is adapted to the students and the use they can make of knowledge), when the students evaluate positively the teaching which they receive, when the teaching is based on the discussion and when the procedures of evaluation aim to measure processes more than results (Bourgeois, 2006). This fact joins our observations. Our study also found that $67.7 \%$ of the students felt that they were correctly and fairly assessed $(p<0.001)$. The scores obtained are in line with the work of Bernard, Postiaux \& Salcin (2000). This can be linked to an improvement in student learning, via an improvement in the lessons given. Indeed, whatever the institutional context of recognition of the teaching profession of academics, so that the EEE can be part of a logic of Professional Pedagogical Development (DPP), it is necessary that the results are useful to teachers and that teachers give credit to its results so that it can be viewed from the angle of Evaluation-Advice, which follows from formative evaluation or "evaluation for learning" (Lanares, 2009). This involves offering university teachers to go beyond the observation, by engaging in a reflex- 
ive practice that is part of a continuum from reflection to action (Schön, op.cit.).

While the percentages of student responses on the feeling of having developed general skills, $71.1 \%$ of the subjects were "in agreement" $(p<0.01)$. Our findings go hand in hand with the conclusions of the work of De Ketelé (op cit) who maintains that competence is an ordered set of capacities, activities which are exerted on contents in a given category of situations to solve problems posed by those -this. Thus, he distinguishes three structural elements of competence: content, capacity and situation. We will say in this regard that "a competence is a power which the learner possesses and which allows him to mobilize and integrate into a coherent whole knowledge, know-how and life skills in order to solve problems in life situations ". As for the development of transversal skills through teaching, $57.8 \%$ of students leaned towards "strongly disagree" with a highly significant difference $(p<0.05)$. This shows that the students surveyed are not able to exercise in a broad spectrum several situations which do not belong only to pedagogy. In this regard, Jonnaert (2009) finds that a transversal competence allows the subject to use a stabilized operating network of capacities and skills in many situations which do not necessarily belong to pedagogy, class of situation. According to Mario \& Bissoneetee (2001), these transversal skills are common to several tasks, activities, functions, trades and reusable in a large number of situations.

As for the development of specific skills, $56.7 \%$ of the subjects answered "not at all in agreement" ( $p<0.05$ Table 5). Thus, our master students do not have the capacity to satisfactorily manage complex projects. The definition reported by Délignières (2014) confirms this estimate. According to this author, a skill can be defined as the ability to successfully manage complex projects. It is a question of initially distinguishing oneself from the concept of task, in its most classic acceptance which returns to a clearly defined and delimited situation in space and time, to reach a goal by taking into account a number of conventional constraints.

\subsection{Study System Organization}

Our data also show that $67.8 \%$ of students $(p<0.05)$ were not aware of the examination regime and knowledge testing methods at the start of the semester. This observation is due to the lack of prior information from certain groups of teachers. Information indicates both the message to be communicated and the symbols used to write it. It is linked to a project and can be built in advance as a program.

With regard to satisfaction with the organization of the test (Table 5), 40.1\% of the students' responses $(p<0.05)$ said "completely agree". This can be justified by the involvement of students in the assessment process. According to Younès (2009), it is important that students are more and more involved in the evaluation process because they are the first to benefit from it. Teachers should be able to indicate whether their presentations are clear, whether comments on 
the work help them to progress, whether the documents used promote understanding. Students must also witness their performance. Since the teaching-learning process is complex, its evaluation therefore requires the use of a method that takes into account all of the dimensions that cover it in its entirety. This is how Bernard (op. Cit.) Considers that evaluating a teacher's teaching means gathering information on the quality of his teaching work.

Similarly, the responses related to satisfaction with the planning and pace of the lessons, $64.4 \%$ of the students were "completely in agreement", with a statistically significant difference in percentages $(p<0.05)$. This may be dependent on the new Master's Doctorate (L.M.D) system accepted since 2005 by Marien Ngouabi University. For the hourly volumes allocated to teaching, $71.1 \%$ of students "agreed" with them $(p<0.01)$. This can be explained by the number of credits granted to each discipline. A full course includes eight (8) years of training (from bac +1 to bac +8 ), or sixteen (16) semesters. Each semester corresponds to thirty (30) credits. At the end of the course, the student therefore has four hundred and eighty (480) credits. Finally $68.9 \%$ of the students declared that they were satisfied with the material conditions $(p<0.01)$. Indeed, the L.M.D. adopted by all the countries of sub-Saharan French-speaking black Africa, competition to harmonize the offer of university training with European, American, Middle Eastern and Asian countries. The aim of this approach is to facilitate international comparisons and equivalences, then to promote student mobility and their access to the world of work.

\section{Limitations}

However, the interpretation of our results must take into account certain limits. The first is due to the very type of study and its cross-cutting nature which only allows for a time snapshot. The conduct of a longitudinal interview-based survey would have been better suited to the identification of relevant indicators for evaluating the lessons given by the trainers of this institute. The second limitation relates to the mode of expression of the grouped data, not taking into account the gender of the students surveyed. These limits mentioned do not, however, completely affect the power of our observations. In any case, this study is the first of its kind in our community. Other surveys including BA students should help validate the data obtained.

\section{Conclusion}

The aim of this study was to assess by future physical education teachers (master students) quality of course content, assessments and teaching strategies implemented by the trainers. The results obtained confirm our hypotheses, and show that physical education students have the possibility of better judging or evaluating certain objects of evaluation in order to bring about considerable changes in the teaching process. Indeed, according to the answers obtained, it emerges for the students: 1) the good construction of skills, through the choice 
of teaching objectives, the management of the space of freedom and the adjustment of training by evaluating the learner progress; 2) adequate resource mobilization; 3) a sufficient level of teacher investment, thus allowing the contribution of the processes and resources involved. The opposite effects are due to the inexperience of the students. In other words, this study allowed us to understand, in part, the impact of assessment by learners on learning objects and the quality of teaching. Consequently, the evaluation of the lessons taken by the future physical education teachers themselves helps to optimize the choices of pedagogical and didactic intervention of the teacher, but also to help the latter in the choice and adjustment of its educational procedures.

\section{Conflicts of Interest}

The authors declare no conflicts of interest regarding the publication of this paper.

\section{References}

Akerlind, G. S. (2005). Academic Growth and Development: How Do University Academics Experience It? Higher Education, 50, 1-32. https://doi.org/10.1007/s10734-004-6345-1

Amade-Escott, C. (1991). Caractérisation de la formation didactique initiale des enseignants d'éducation physique et évaluation de ses retombées sur les compétences professionnelles. Thèse de doctorat non publiée, Toulouse: Université de Toulouse.

Baillauquès, S. (1996). Le travail des représentations dans la formation des enseignants. In L. Paquay, M. Altet, É. Charlier, \& P. Perrenoud (Eds.), Former des enseignants professionnels. Quelles stratégies? Quelles compétences? (pp. 41-62). Bruxelles: De Boeck.

Bélair, L. (1996). La formation à la complexité du métier d'enseignant. In L. Paquay, M. Altet, É. Charlier, \& P. Perrenoud (Eds.), Former des enseignants professionnels. Quelles stratégies? Quelles compétences?(pp. 63-75). Bruxelles: De Boeck.

Bernard, H. (2011a). Comment évaluer, améliorer, valoriser l’enseignement supérieur? Bruxelles: De Boeck.

Bernard, H. (2011b). L'évaluation de l'enseignement universitaire. Bruxelles: De Boeck.

Bernard, H., Postiaux, N., \& Salcin, A. (2000). Les paradoxes de l'évaluation de l'enseignement universitaire. Revue des Sciences de l'Education, 26, 625-650.

https://doi.org/10.7202/000293ar

Bourgeois, E. (2006). L'évaluation en question. Paris: Presses Universitaires de France.

Braskamp, L. A., \& Ory, J. C. (1994). Assessing Faculty Work: Enhancing Individual and Institutional performance. San Francisco, CA: Jossey-Bass.

Brookfield, S. (1992). Uncovering Assumptions: The Key to Reflective Practice. Adult Learning, 18, 13-14. https://doi.org/10.1177/104515959200300405

Bru, M. (2002a). Pratiques enseignantes: Des recherches à confronter et à développer. Revue Française de Pédagogie, 138, 63-73. https://doi.org/10.3406/rfp.2002.2864

Bru, M. (2002b). Savoirs de la recherche et savoirs des praticiens de l'enseignement: Jeu de dupes ou rencontre ouverte et constructive? In M. Bru, \& J. Donnay (Eds.), Recherches, pratiques et savoirs en éducation (pp. 133-154). Bruxelles: De Boeck Supérieur, coll. Perspectives en éducation et formation. 
Calderhead, J. (1992). The Role of Reflection in Learning to Teach. In L. Valli (Ed.), Reflective Teacher Education: Cases and Critiques (pp. 139-146). New York: SUNY Press.

Coggi, C., \& Maccario, D. (2009). Contribution des étudiants à l'évaluation de la didactique universitaire: Une réduction à de plus justes propositions. In M. Romainville, \& C. Coggi (Eds.), L'évaluation de l'enseignement par les étudiants (pp. 167-189). Bruxelles: Editions De Boeck.

Cordova, D. I., \& Lepper, M. R. (1996). Intrinsic Motivations and the Process of Learning: Beneficial Effects of Contextualization, and Choice. Journal of Educational Psychology, 88, 715-730. https://doi.org/10.1037/0022-0663.88.4.715

Cros, F. (2012). L'innovation scolaire aux risques de son évaluation. Paris: L'Harmattan.

Cyruslnik, L. (2014). L'évaluation, approche descriptive et prescriptive. Paris: Presses Universitaires de France.

De Ketelé, J. M. (2010). La pédagogie universitaire: Un courant en plein développement. Revue Française de Pédagogie, 172, 5-13.

Délignières, D. (2014). Vers une pédagogie des compétences: Apprendre à gérer la complexité. In M. Quidu (Ed.), Innovation théoriques en STAPS et implications en EPS (pp. 478-489). Paris: L'Harmattan.

Doyle, J. J. O. (1983). Evaluating Teacher. Lexington, MA: Ed. Books.

Hein, B., \& Koka, H. G. (2007). Théorie et pratique de l'évaluation dans la pédagogie des activités physiques et sportives. Paris: Editions Vigot.

Hiebert, J., Gallimore, R., \& Stigler, J. W. (2002). A Knowledge Base for the Teaching Profession: What Would It Look Like and How Can We Get One? Educational Research, 31, 3-15. https://doi.org/10.3102/0013189X031005003

Jonnaert, Ph. (2009). Compétences et socioconstructivisme. Bruxelles: De Boeck. https://doi.org/10.3917/dbu.jonna.2009.01

Lanares, J. (2009). L'évaluation-conseil dans l'enseignement universitaire en Suisse. In V. Bedin (Ed.), L'évaluation à l'université: Évaluer ou conseiller? (pp. 211-232). Rennes: Presses Universitaires de Rennes.

Mario, R., \& Bissoneetee, S. (2001). Comment construire des compétences en classe. Montréal: Chènevière/McGraw Hill.

Paquay, L., Van Nieuwenhoven, C., \& Wouters, P. (2010). L'évaluation, levier du développement professionnel? Tensions, dispositifs, perspectives. Bruxelles: Editions De Boeck.

Perret, C., \& Demougeot-Lebel, J. (2014). Le caractère formatif d'un dispositif d'évaluation des enseignements par les étudiants (EEE): Une analyse de l'utilité des questionnements pour une démarche réflexive? Mesure et Evaluation en Education, 37, 41-67. https://doi.org/10.7202/1035913ar

Piccinin, S. (1999). How Individual Consultation Affects Teaching. In C. Knapper, \& S. Piccinin (Eds.), Using Consultants to Improve Teaching (pp. 71-84). New York. https://doi.org/10.1002/tl.7908

Poissant, H. (1996). L'évaluation d'enseignements Universitaire. Montréal: Editions Logiques.

Reboul, O. (1980). Qu'est-ce qu'apprendre? Paris: PUF.

Romainville, M. (1997). L’enseignement universitaire a les étudiants qu'il mérite... In M. Frenay, B. Noël, P. Parmentier, \& M. Romainville (Eds.), L'étudiant-apprenant, grilles de lecture pour l'enseignant universitaire (pp. 95-108). Bruxelles: De Boeck.

Rossi, P. H., \& Freeman, H. E. (1985). Evaluation: A Systematic Approach. Beverly-Hills, 
CA: Sage Publications.

Schön, D. A. (1983). The Reflective Practitioner: How Professionals Think in Action. New-York: Ed. Basic Books.

Seldin, P. (2006). Evaluating Faculty Performance. A Practical Guide to Assessing Teaching, Research, and Service. Bolton: Anker Publishing.

Sokal, R. F., \& Rohlf, S. W. (1995). Biometry (7th ed.). San Francisco, CA: Freeman and Co.

Younès, N. (2009). L'évaluation de l'enseignement par les étudiants comme seuil de changement. In M. Romainville, \& C. Coggi (Eds.), L'évaluation de l'enseignement par les étudiants (pp. 191-211). Bruxelles: Editions De Boeck. 